\title{
Production of Recycled Plastic Coarse Aggregates and its Utilization in Concrete
}

\author{
Ajey Kumar V G ${ }^{1}$, Karthik $\mathbf{M}^{2}$, Dr. Mangala Keshava ${ }^{3}$ \\ ${ }^{1}$ Juniour Research Fellow- ISRO Respond, Sri Venkateshwara College of Engineering, Bengaluru, India, \\ ajeyhosadurga@gmail.com \\ ${ }^{2}$ Research Scholar, Department of Civil Engineering, BMS College of Engineering, Bengaluru, India, \\ karthikm.phdbmsce@gmail.com \\ ${ }^{3}$ Associate Professor, Department of Civil Engineering, B M S College of Engineering. Bengaluru, India, \\ mk.civ@bmsce.ac.in
}

\begin{abstract}
Aggregates are the most consumed natural resource in construction. Increase in the consumption of natural aggregates results in depletion of natural resources and in turn affects the environment. In recent years plastic wastes is increasing constantly. These plastic wastes are discarded or landfilled which is directly affecting the environment. Management of plastic waste has become a serious issue over the world. Depletion in natural resources and enormous plastic waste generation gives an opportunity to find an alternative to natural aggregates. In this context, Recycled Coarse Aggregates (RCA) obtained from waste plastic is one of the ways of reducing the consumption of natural resources. In the present study an attempt has been made to utilize waste plastic as an alternative for coarse aggregate. It consists of collection of statistics of plastic wastes generated and studying its composition. Major types of contributors in plastic waste generation, such as High Density Polyethylene (HDPE), Low Density Polyethylene (LDPE) and Polypropylene Ether (PPE) plastic types were considered for production of alternative coarse aggregates. M-30 concrete mix made with alternate waste plastic coarse aggregates upto $30 \%$ replacement of HDPE, upto $20 \%$ replacement of LDPE and upto $30 \%$ replacement of PPE were found to exhibit 30MPa compressive strength.
\end{abstract}

Key words: Recycled coarse aggregates, Concrete, HDPE, LDPE, PP

\section{INTRODUCTION}

The increase in construction activities has drastically increased demand for natural resources all over the world, which has gradually decreased the availability of natural resources and due to a decrease in the availability, cost of construction materials are increasing day by day. Plastic waste can be utilized as a useful resource in construction industries. Utilization of waste in construction industries, plays a vital role in the preservation of environment and decrease in utilization of natural resources in the future. Utilization of waste obtained from plastic in concrete could be one of the ways of utilizing the plastic waste effectively. Many nations have started considering this plastic waste as a resource and are working out on the best ways where plastic waste can be utilized in construction field effectively. The average plastic waste produced in 60 major cities was about $6.92 \mathrm{Kg} / \mathrm{MT}$ per day, i.e. $6.92 \%$ of total municipal solid waste as per the survey conducted by the central union pollution control board. Consumption of plastic in India is about 13 million tonnes per year and 9 million tonnes of plastic waste is generated per year, in that only $60 \%$ of the waste produced from plastic is getting recycled and remaining $40 \%$ of plastic waste is disposed of without environmental considerations. Plastic takes 450 to 1000 years for complete decomposition which is a serious issue. Utilization of plastic waste in various fields has become a common application everywhere in the globe. In concrete, it's typically used for lower grade applications like usage in pavements, low-grade concrete, etc. Proper utilization of waste plays a vital role in making a country developed. Improper utilization of waste leads to environmental pollution and leads to a disease-causing environment[1][3].

\section{PLASTIC PRODUCTION AND WASTE GENERATION}

\subsection{Plastic Production}

Plastic items have turned into a noteworthy essential piece of our day by day lives, urging their generation to cross 150 million tons for each year. The packaging is a standout amongst the most significant uses of plastics and also the single-biggest division of plastics used and records for $35 \%$ of plastic utilization. More than 30000 authorized plastic processing units are currently operating in India as shown in table 1. There are many unauthorized small and medium ventures operating in plastic processing [3].

Table 1: Plastic Production in India Snapshot of the Indian Plastics Processing Industry

\begin{tabular}{ll|}
\hline \multicolumn{2}{|c|}{ Snapshot of the Indian Plastics Processing Industry } \\
\hline Estimated size of plastic processing in value (P15) & IINR 1 lakh croore \\
\hline Market size in volume (P15) & 13.4 MMTPA \\
\hline Processing Units & $>30,000$ \\
\hline Technical manpower (as per CIPET) & 11 lakh employees \\
\hline Growth Rate & $10-11 \%$ \\
\hline Per Capita Plastic Consumption & $11 \mathrm{~kg}$ (Vorld: 28kg)
\end{tabular}


From figure 2 the normal per capita utilization of plastic in India is around $11 \mathrm{~kg}$, which is significantly low when compared with the worldwide per capita consumption of $28 \mathrm{~kg}$ [5].

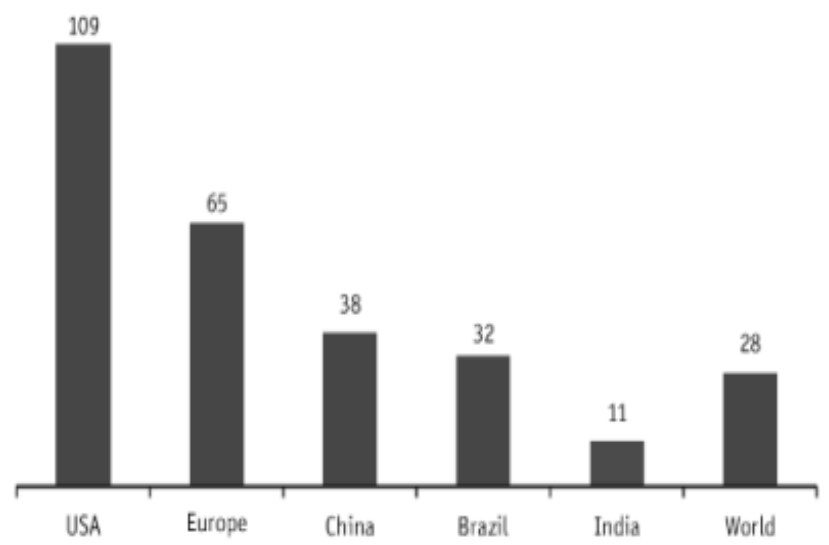

Figure 1: Per capita plastic consumption

\subsection{Plastic Waste Generation}

Plastic items have turned into a vital piece of everyone's day by day life needs. It crosses 150 million tons of production for each year internationally. In India, roughly 13 million tons of plastic is created every year.

The fresh municipal solid waste generated in sixty cities was found to be 50592 MT/ day, which consists of organic waste, dust, paper, plastic, glass, metal, biomedical waste, cardboard, rubber, and other wastes. The total amount of municipal waste generated in Bengaluru city was about $1700 \mathrm{M} /$ day to $2300 \mathrm{MT} /$ day, the average plastic waste generated was found to be $6.9 \mathrm{Kg} / \mathrm{MT}$ i.e., $6.9 \%$ of plastics waste generated in total municipal solid waste [1].

Table 2: MSW composition( Source- CPCB)

\begin{tabular}{|c|c|}
\hline Type of Waste & \% of waste in MSW \\
\hline Organic & 61 \\
\hline Dust & 5 \\
\hline Paper & 12 \\
\hline Plastic & $\mathbf{1 4}$ \\
\hline Glass & 4 \\
\hline Metal & 1 \\
\hline Bio-Medical & 1 \\
\hline Rubber & 1 \\
\hline Others & 1 \\
\hline
\end{tabular}

India produces 25940 tons of plastics waste each day, but more than $40 \%$ of it stays uncollected causing drainage blockages, soil and water contamination, and outside burning of plastics affect human wellbeing and environmental conditions. It is noticed that almost $1 / 6^{\text {th }}$ of the plastic waste is created by 60 urban areas in India, with Delhi, Chennai, Kolkata, Mumbai, and Bengaluru together producing over half of the total contribution in India. Composition of plastic waste in Bengaluru is shown in table 3.
Table 3: Composition of plastic waste in Bengaluru

\begin{tabular}{cccccccc}
\hline $\begin{array}{c}\text { SERIAL } \\
\text { OF DAYS }\end{array}$ & PET & HDPE/LDPE & PVC & PP & PS & OTHER & \\
\hline DAY 1 & 2.1 & 90.8 & 1 & 0.64 & 0.88 & 1.7 & 97.12 \\
\hline DAY 2 & 0.94 & 67.8 & 0.74 & 0.9 & 0.64 & 1.52 & 72.54 \\
\hline AVERAGE & 1.52 & 79.3 & 0.87 & 0.77 & 0.76 & 1.61 & 84.83 \\
\hline
\end{tabular}

Table 4: Consolidated plastic waste composition in India

\begin{tabular}{|c|c|c|c|}
\hline S.NO & CODES & DESCRIPTION & $\begin{array}{c}\text { TOTAL } \\
\text { PERCENTAGE } \\
\text { OBTAINED }\end{array}$ \\
\hline 1 & (i) & PET & 8.66 \\
\hline 2 & (2) 20 & HDPE/LDPE & 66.91 \\
\hline 3 & (3). & PVC & 4.14 \\
\hline 4 & (5) & PP & 9.9 \\
\hline 5 & (6) & PS & 4.77 \\
\hline 6 & 20 & OTHERS & 6.43 \\
\hline
\end{tabular}

By considering the above statistics of plastic waste generation from Table 4, it is decided to consider three major contributors of plastic waste types HDPE, LDPE and PPE or the production of alternative coarse aggregates and its utilization in concrete.[11]

\section{EXPERIMENTAL PROGRAMME}

For the production of alternative waste plastic coarse aggregates mechanical method was adopted. Plastic wastes were collected and segregated according to different types of plastics, segregated plastic waste were cleaned and introduced into washing unit, thereafter plastics were introduced into burning chamber of $250^{\circ} \mathrm{C}-300^{\circ} \mathrm{C}$ temperature and output was further placed into shredding machine as shown in Figure 2. [6][9]

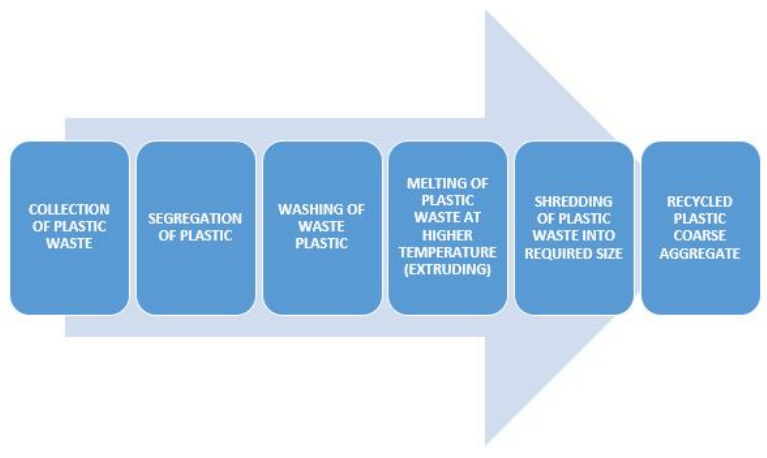

Figure 2: Plastic aggregate production flowchart

Figure 3, 4 and 5 exhibit HDPE, LDPE and PPE aggregates that was obtained after processing the respective plastic wastes. Figure 6 shows the picture of typical natural aggregates. 


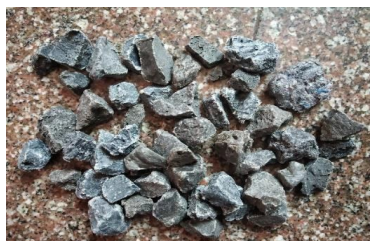

Figure 3: HDPE aggregate

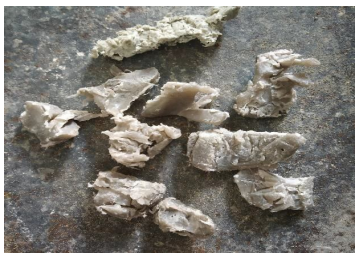

Figure 5: LDPE aggregate

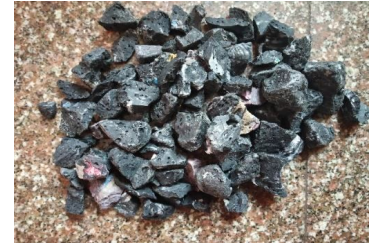

Figure 4: PPE aggregate

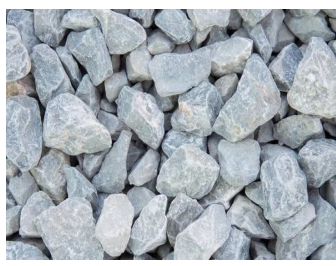

Figure 6: Natural aggregate
The recycled waste plastic coarse aggregates and natural coarse aggregates were tested as per IS codes. Tests like specific gravity, water absorption, fineness modulus, bulk density, \% voids, shape tests, strength tests and temperature test on aggregates were conducted \& results are reported in Table 5 along with the properties of natural aggregates.

Table 5: Aggregate test results

\begin{tabular}{|c|c|c|c|c|c|}
\hline $\begin{array}{c}\text { Sl } \\
\text { No. }\end{array}$ & TEST & HDPE & LDPE & PPE & $\begin{array}{l}\text { Natural } \\
\text { aggregates }\end{array}$ \\
\hline 1 & $\begin{array}{l}\text { Specific } \\
\text { Gravity }\end{array}$ & 1.04 & 0.93 & 0.9 & $2.5-2.9$ \\
\hline 2 & $\begin{array}{l}\text { Water } \\
\text { absorption (\%) }\end{array}$ & 0.05 & 0.04 & 0 & $<2 \%$ \\
\hline 3 & $\begin{array}{l}\text { Bulk } \\
\text { Density }\left(\mathrm{kg} / \mathrm{m}^{3}\right) \\
\&(\% \text { Voids })\end{array}$ & $\begin{array}{c}540 \\
(46 \%)\end{array}$ & $\begin{array}{c}340 \\
(63.4 \%)\end{array}$ & $\begin{array}{c}490 \\
(52.2 \%)\end{array}$ & $\begin{array}{c}1200-1750 \\
\mathrm{~kg} / \mathrm{m}^{3}\end{array}$ \\
\hline 4 & $\begin{array}{l}\text { Fineness } \\
\text { Modulus }\end{array}$ & 6.82 & 6.88 & 6.92 & $6-6.9$ \\
\hline 5 & $\begin{array}{l}\text { Flakiness } \\
\text { Index }\end{array}$ & $11.21 \%$ & $15 \%$ & $10.21 \%$ & $<30 \%$ \\
\hline 6 & $\begin{array}{l}\text { Elongation } \\
\text { Index }\end{array}$ & 18 & 40 & 16.9 & $<15 \%$ \\
\hline 7 & $\begin{array}{l}\text { Angularity } \\
\text { Number }\end{array}$ & 13.66 & 33.01 & 13.19 & $0-10$ \\
\hline 8 & $\begin{array}{l}\text { Crushing } \\
\text { Strength }\end{array}$ & 0 & 0 & 0 & $<30 \%$ \\
\hline 9 & Impact Test & 2.4 & 2.3 & 0 & $<20 \%$ \\
\hline 10 & Abrasion Test & 0 & 0 & 0 & $<40 \%$ \\
\hline
\end{tabular}

\subsection{Concrete mix proportioning}

Concrete mix design prepared considering with and without recycled waste plastic coarse aggregates replacing with volume fraction. Ordinary Portland cement of 53 grade is used throughout the study. Manufactured sand confirming to zoneII is used. The physical properties of $\mathrm{M}$ sand are determined as per IS 2386 (Part II) - 1963. The mix proportion is prepared for M30 grade of concrete with the target strength of 38.25 $\mathrm{MPa}$.

Water-cement ratio was fixed to 0.45 . Water content was fixed to $197 \mathrm{~kg} / \mathrm{m}^{3}$ for all the concrete mixes. Natural coarse aggregates of same grading (grading of recycled waste plastic aggregates) were used for concrete mixes for better comparison. The specific gravity of cement is found to be 3.15. Concrete mixes prepared with CM, H1, H2, H3, L1, L2, $\mathrm{L} 3, \mathrm{P} 1, \mathrm{P} 2$ and $\mathrm{P} 3$ respectively. Mix proportioning is prepared for M30 grade of concrete by utilizing waste plastic recycled coarse aggregates by replacing $0 \%, 10 \%, 20 \%$ and $30 \%$ of natural coarse aggregates in volumetric fraction.[10]

\subsection{Workability test (Slump Test)}

The workability of various concrete mixes in terms of slump value is presented graphically in Table 6 . The variation in the slump values of concrete mixes is studied.

Table 6: Workability test results

\begin{tabular}{|l|l|}
\hline MIX & SLUMP in mm \\
\hline CM & 60 \\
\hline H1 & 50 \\
\hline H2 & 45 \\
\hline H3 & 40 \\
\hline L1 & 40 \\
\hline L2 & 30 \\
\hline L3 & 25 \\
\hline P1 & 45 \\
\hline P2 & 45 \\
\hline P3 & 40 \\
\hline
\end{tabular}

\subsection{Hardened properties of concrete}

To obtain strength property of different design mix concrete, compressive strength, tensile strength and flexural strength tests were conducted and thus obtained strength results for all the 10 concrete mixes is presented in Figure 7, 8 and 9 as per IS: 516-1959.

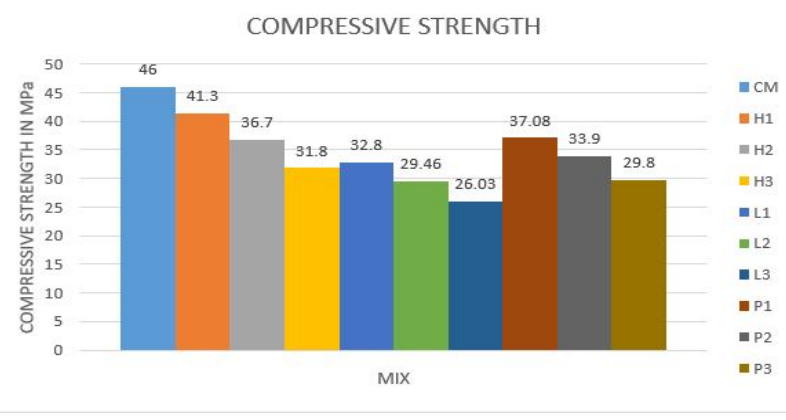

Figure 7: Compressive strength test results 


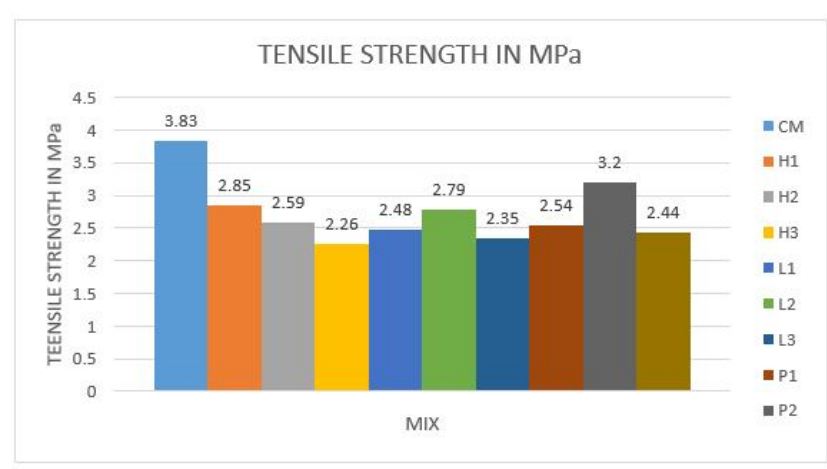

Figure 8: Tensile strength test results

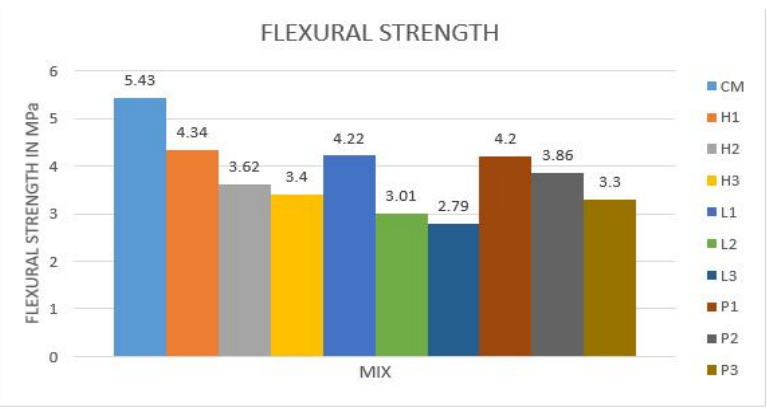

Figure 9: Flexural strength test results

\subsection{Durability test for waste plastic utilized concrete}

The durability of concrete mixes is conducted by exposing concrete cubes of $100 \mathrm{~mm}$ at a higher temperature in a muffle furnace. Concrete cube specimens were subjected to $75^{\circ} \mathrm{C}$ and $200^{\circ} \mathrm{C}$ for 60 minutes. Compressive strength of concrete cubes after temperature exposure was tested [7][8].

Table 7: Durability test results in MPa

\begin{tabular}{|l|l|l|l|l|}
\hline TEMPERATURE & CONVENTIONAL & HDPE & LDPE & PPE \\
\hline $75^{\circ} \mathrm{C}$ & 45.60 & 35.11 & 24.31 & 32.2 \\
\hline $200^{\circ} \mathrm{C}$ & 44.74 & 31.68 & 28.13 & 27.2 \\
\hline
\end{tabular}

\section{RESULT AND DISCUSSIONS}

The workability of various concrete mixes is in terms of slump value. The variation in the slump values of concrete mixes is studied. However the huge variation in slump values cannot be seen in the concrete mixes which was produced utilizing waste plastic. LDPE aggregates used in concrete mixes showed lesser slump values when compared to other concrete mixes due to the irregular shape of aggregates obtained. The decrease in slump values is seen in all concrete mixes compared to that of conventional concrete mix. Therefore increase in the $\%$ plastic aggregates as a replacement for natural coarse aggregates resulted in a decrease in slump value.

Compressive strength reduced as increase in percentage of plastic aggregate replacement to coarse aggregates. Target strength of the concrete mixes achieved but LDPE mix with
$30 \%$ replacement of coarse aggregates failed to achieve the target strength.

Replacement of natural coarse aggregates by LDPE and PPE resulted in a decrease in tensile strength at $10 \%$ replacement, but by replacing $20 \%$ of PPE and LDPE, aggregates tensile strength increased up to $3.20 \mathrm{MPa}$ and a further increase in $\%$ replacement resulted in a decrease in tensile strength.

Replacement of coarse aggregates by recycled plastic coarse aggregates of HDPE, LDPE, and PPE resulted in a decrease in flexural strength. With increase in $\%$ of replacement of waste plastic coarse aggregates flexural strength decreased in all the 3 types of plastic aggregate mixes.

Compressive strength of concrete cubes after temperature exposure was tested. At $200^{\circ} \mathrm{C}$ of temperature concrete specimens started spalling and cracks were seen on the cubes. Compressive strength of alternative mixes decreased when compared to the conventional mix specimen after temperature exposure.

\section{CONCLUSION}

In the present study an attempt has been made to utilize waste plastic as an alternate for coarse aggregates. Major contributors in plastic waste generation, such as High Density Polyethylene (HDPE), Low Density Polyethylene (LDPE) and Polypropylene Ether (PPE) plastic types were considered for production of alternative coarse aggregates. Recycled plastic coarse aggregates were produced through a mechanized process. Characteristic properties of recycled plastic aggregates were examined. The specific gravity and water absorption of recycled plastic coarse aggregates was found to be very low when compared to natural coarse aggregates. Fineness modulus and bulk density were found to be within acceptable range. Flakiness index, elongation index and angularity number were found to be within the codal specification. Impact value, crushing value and abrasion value of RPCA is within the acceptable range as per codal provisions to be used in concretes for both wearing and non-wearing surfaces. The temperature withstanding capacity of RPCA is less than $200^{\circ} \mathrm{C}$ in all the three types of aggregates. Higher the temperature aggregates started melting and burnt at $300^{\circ} \mathrm{C}$.

The fresh and hardened properties of M-30 concrete mix made with waste plastic coarse aggregates are determined and compared with conventional concrete made with natural aggregates. Workability properties of concrete made with recycled plastic coarse aggregates decreased with increase in percentage. However the compressive strength of M-30 concrete mix made with recycled plastic coarse aggregates (HDPE and PPE) reached the target strength. Tensile and flexural strengths decreased with increase in plastic aggregates replacement. Compressive strength of concrete mix marginally decreased after temperature exposure in a muffle furnace. Therefore from the present study M-30 concrete mix made with varying percentage of replacement of RPCA such as 10\%, 20\%, 30\%, 40\% and 50\% showed decrease in compressive strength. However, upto $30 \%$ replacement of HDPE, upto 20\% replacement of LDPE and 
$30 \%$ replacement of $\mathrm{PPE}$ exhibited $30 \mathrm{MPa}$ compressive strength and hence were found to be suitable.

\section{ACKNOWLEDGEMENT}

I would take this opportunity to express my sincere thanks to Dr. Mangala Keshava, Associate Professor, Department of Civil Engineering, BMSCE. I sincerely thank B M S College of Engineering for providing facilities and constant support.

\section{REFERENCES}

1. Central Pollution Control Board, Ministry of environment, forest \& climate change, "Assessment and characterization of plastic waste generation in 60 major cities", Publication January 2015.

2. https://www.thoughtco.com/history-of-plastics-19923 22

3. Environmental management \& policy research institute, "Plastic and its harmful effects", Issue 42, OctoberDecember 2016.

4. R R N Sailaja Bhattacharya, Kaushik Chandrashekar, M V Deepthi, Pratik Roy, and Ameen Khan, 'Challenges and opportunities, Plastic waste management in India", The Energy and Resource Institute.

5. Central Pollution Control Board, Ministry of environment, forest \& climate change, " Life Cycle Assessment study of plastics packaging products", Publication March 2018.

6. Ashwini Manjunath B T, "Partial replacement of E-plastic Waste as Coarse-aggregate in Concrete", International Conference on Solid Waste Management, 5IconSWM 2015, Procedia Environmental Sciences 35 (2016) $731-739$.

https://doi.org/10.1016/j.proenv.2016.07.079

7. K.Senthil Kumar and K.Baskar, "Effect of temperature and thermal shock on concrete containing hazardous electronic waste", ASCE, Waste, 2018, 22(2): 04017028.

8. Togay Ozbakkaloglu, Lei Gu; and Aliakbar Gholampour, "Short-term mechanical properties of concrete containing recycled polypropylene coarse aggregate under ambient and elevated temperature", J. Mater.Civ.Eng., 2017, 29(10):04017191 ASCE.

9. Mehdi Seghiri, Djamel Boutoutaou, Abdelouahed Kriker, Mohamed Ibrahim Hachani, "The possibility of making a composite material from waste plastic", Procedia Volume 119, July 2017, Pages 163-169. https://doi.org/10.1016/j.egypro.2017.07.065

10. K. Harish Kumar, K. Chandra Venkata Shabarish , G. Bhanu , K. Durga Vara Prasad, Ch. Satish Kumar "An Experimental Study on Effect of Replacing Natural Sand by Quarry Dust and Saw Dust on Properties of Concrete", International Journal of Emerging Trends in Engineering Research, Volume 8. No. 5, May 2020, ISSN $2347-3983$ https://doi.org/10.30534/ijeter/2020/71852020

11. Feras Al Adday, "Selecting the Best Method for Adding Recycled Aggregate and Waste Bags to Asphalt Pavement", International Journal of Emerging
Trends in Engineering Research, Volume 8. No. 6, June 2020, ISSN 2347 - 3983

https://doi.org/10.30534/ijeter/2020/08862020

12. https://timesofindia.indiatimes.com/india/india-generate s-26k-tonne-plastic-waste-everyday-40-remains-uncolle cted/articleshow/67646745.cms.

13. IS: 456-2000, "Indian standard plain and reinforced concrete- code of practice", Bureau of Indian standards, New Delhi.

14. IS: 2386 (Part III) - 1963 (reaffirmed 1997). "Indian standard methods of test for aggregates for concrete", Bureau of Indian standards, New Delhi.

15. IS: 2386 (Part IV) - 1963 (reaffirmed 1997). "Indian standard methods of test for aggregates for concrete", Bureau of Indian standards, New Delhi.

16. IS: 2386 (Part 1)-1963 (reaffirmed 1997). "Indian standard methods of test for aggregates for concrete", Bureau of Indian standards, New Delhi.

17. IS: 383-1970 "Indian standard specification for coarse and fine aggregates from natural sources for concrete", Bureau of Indian standards, New Delhi.

18. IS: 10262-2009. "Indian standard recommended guidelines for concrete mix design", Bureau of Indian standards, New Delhi.

19. IS: 516-1959 (reaffirmed 1999), "Indian standard methods of test for strength of concrete", Bureau of Indian standards, New Delhi.

20. IS: 1199-1959 (reaffirmed 1999), "Indian standard methods of sampling and analysis of concrete", Bureau of Indian standards, New Delhi. 